\title{
FREE EXERCISE: RELIGION GOES TO "POT"
}

Dr. Timothy Leary was arrested at the American border station in Loredo, Texas after trying unsuccessfully to enter Mexico. A thorough search of his car revealed less than one-half of an ounce of marihuana. Subsequently, he was convicted by a jury for violation of federal marihuana laws ${ }^{1}$ and sentenced to thirty years in prison and forty thousand dollars in fines. ${ }^{2}$ The Fifth Circuit, affirming the conviction in Leary $v$. United States, ${ }^{3}$ held the absolute prohibition of marihuana to be a compelling governmental interest. The court found that a religious exemption would seriously impair the purpose of these laws.

The first amendment to the United States Constitution provides that "Congress shall make no law respecting an establishment of religion, or prohibiting the free exercise thereof ...." Establishment and free exercise are two distinct concepts. The focus of this Comment will be exclusively on the free exercise clause.

Proper analysis of the Fifth Circuit's decision requires consideration of the historic roots and subsequent evolution of the free exercise clause. Attempts to reconcile the cases dealing with free exercise from 1878 to the present are unavailing. Until recently, freedom of religion had been an almost totally ineffectual defense against governmental regulation infringing on religious activity. During the last twenty-eiglit years, however, the concept has undergone radical alteration from a hollow riglit to believe to a substantive right to act. This change must be analyzed with a view to society's understanding of what actions are "religious" and what governmental interests are sufficient to justify infringing on such actions.

This Comment will not undertake the task of determining what elements are necessary to classify beliefs as religious. The Fifth Circuit assumed that Leary used marihuana for religious purposes before determining whether such religious use would be protected by the first amendment. Courts have traditionally refrained from deciding what constitutes a religion. Some lower courts have made such an attempt. ${ }^{4}$ The Supreme Court,

121 U.S.C. $\S 176(a)$ (1964) (possession of marihuana), and The Marihuana Tax Act, 26 U.S.C. $\$ 4744(a)(2)$ (1964).

2 His sentence may be reduced upon final disposition of the case under 18 U.S.C. $\S 4208$ (b) (1964) by the federal district court judge. However, conviction under 21 U.S.C. \$176(a) (1964) requires a mandatory sentence of five years, and under 26 U.S.C. $\$ 7237$ (d) (1964) there can be no suspension of sentence or probation for such conviction.

3383 F.2d 851 (5th Cir. 1967).

4 Fellowship of Humanity v. County of Alameda, 153 Cal. App. 673, 315 P.2d 394 (1957); Washington Ethical Soc'y v. District of Colunbia, 249 F.2d 127 (D.C. Cir. 1957). The Fellozeship case set out a four-part definition for a rchigion: a belief, a cult, a system of moral practices, and an organization. The Ethical case included within its definition a devotion to some principle, strict fidelity or faithfulness, and conscientiousness. 
however, has consistently refused to define the term "religion" though they have attempted to determine what are rehigious behefs. ${ }^{5}$ Any general definition would necessarily favor existing rehgions perhaps in violation of the establisliment clause.

I

HISTORICAI DEVELOPMENT OF "FREE EXERCISE" TESTS

\section{A. Secular Regulation Test}

Religious practice of polygamy by Mormons provided the occasion in 1878 for the Supreme Court's first articulation of the meaming of religious freedom. In Reynolds v. United States ${ }^{0}$ the Court drew a distinction between religious beliefs and rehgious acts by formulating what has been called the "secular regulation" rule: ${ }^{7}$ the first amendment does not confer constitutional protection on religious acts that contravene generally applicable legislation; it bestows protection only upon religious beliefs. ${ }^{8} \mathrm{Be}-$ cause antipolygamy laws were constitutional as generally applied, the rehgious practice of polygamy was forced to yield to the statute. The Court, in addition, expressed its deep abhorence of polygamy, stating that the practice undermined the primciples of democracy and fettered people in stationary despotism. ${ }^{9}$

"Justice Clark began his discussion of the term "Supreme Being" in the landmark conscientious objection case, United States v. Seeger, 380 U.S. 163 (1965), by observing that, "[i]n no field of human endeavor has the tool of language proved so inadequate in the communication of ideas as it has in dealing with the fundamental questions of nan's predicament in life, in death or in final judgment and retribution." Id. at 174.

Prior to Seeger the Supreme Court had met this question head on in other selective service cases. See United States v. Macintosh, 283 U.S. 605 (1931), where the essence of a religious belief was defined as a belief in a relation to God involving duties superior to those arising from any human relations.

Seeger bas defined religious behefs in a way that enables the definition to be relatively objectively apphed to any set of behefs. The test is whether the behefs in question have "[a] sincere and meaningful existence which occupied in the bife of its possessor a place parallel to that filled by the God of those admittedly qualifying for the exemption. . . " 380 U.S. at 176 .

The Seeger test does leave somewhat open the problen of distinguishing religious beliefs and purely personal codes since the latter are specifically excluded from exenption from the Selective Service Act. A recent case has indicated that it is not necessary that one's belief relate to forces outside the self. Umited States v. Stolberg, 346 F.2d 363 (7th Cir. 1965). The line between a sincerely held personal code of ethics and a religion positing belief in a "God" of some kind is probably impossible to draw. For a good discussion of these difficult questions see: Rabin, When Is a Religious Belief Religious: US. v. Seeger and the Scope of Free Exercise, 5I CORNELL L.Q. 231 (1966); Comment, Defining Religion: Of God, The Constitution, and the D.A.R., 32 U. CHr. L. REv. 533 (1965).

698 U.S. 145 (1878).

7 D. Manwarng, Render Unto Caeser-The Flag Satute Controversy 51 (1962).

8 This distinction diminishes nuch of the thrust of free exercise. Religious beliefs will normaily not come into question unless they are mamifested in some act.

0 This country has never tolerated plural marriages. Not only has the Supreme Court 
The rule established in Reynolds was applied uniformly by the lower federal and state courts for the following half-century. ${ }^{10}$ There were obvious practical advantages in such a mechanical approach; the courts could avoid the difficult task of weighing interests often involving sensitive questions of religious doctrine. They could strike down any religious belief taking the form of action. However, the expanding concepts of first amendment liberties finally forced a reevaluation of religious freedom. Religious actions ceased to fall before legislation purely because of their secular nature. ${ }^{11}$

\section{B. Emergence of a Balancing Test}

The first erosion of the secular regulation rule occurred in Cantwell $v$. Connecticut, ${ }^{12}$ a case in which freedom of religion and speech were closely interrelated:

Thus the Amendment embraces two concepts,-freedom to believe and freedom to act. The first is absolute, but in the nature of things, the second cannot be.... In every case the power to regulate must be so exercised as not, in attaining a pernissible end, unduly to infringe the protected freedom. ${ }^{13}$

In contrast to the secular regulation rule, the decision implied only that some religious acts will not be subject to generally applicable legislation. ${ }^{14}$ Because Cantwell established no guidelines, courts subsequently faced the delicate problem of determining the circumstances in which religious acts would be exempt from legislation.

Three years later, in a case involving combined questions of speech and religion, the Court used broad language to indicate when religious

upheld laws making polygamy illegal, but it has also upheld laws which disenfranchised anyone who refused to take an oath renouncing polygamy, Davis v. Beason, 133 U.S. 333 (1890), and laws dissolving a church corporation which practiced polygamy, confiscating most of its property. Church of Jesus Christ of Latter Day Saints v. United States, 136 U.S. 1 (1890). The Mormons finally yielded to this government force by renouncing polygamy as a church practice in 1890 . The courts in more recent times have continued to deny the religious practice of polygamy. Cleveland v. United States, 329 U.S. 14 (1946).

10 Knowles v. United States, 170 Fed. 409 (8th Cir. 1909); Shapiro v. Lyle, 30 F.2d 971 (W.D. Wash. 1929); In re Frazee, 63 Mich. 396, 30 N.W. 72 (1886); Owens v. State, 6 Okla. Crim. 110, 116 P. 345 (1911).

11 Manwaring suggests that the "secular regulation rule," thougb it does have flaws, is rooted in logic and practicality. This construction of rehgious freedom fulfills its historic purpose: to protect rehgious worship from the type of rehigious establishment present in England; to respect the "wall of separation" by applying laws uniformly to all regardless of their rehgious affiliation. D. MaNwarnng, supra note 7 , at 52.

12310 U.S. 296 (1940).

13 Id, at 303-04.

14 The last clear articulation of the secular regulation rule was made by Justice Frankfurter when writing for the court in Minersville School Dist. v. Gobitis, 310 U.S. 586 (1940). 
acts would be exempt from legislation. In West Virginia Board of Education v. Barnette ${ }^{18}$ the Court held a school regulation requiring mandatory flag salute unconstitutional as applied to children whose religious tenets forbade saluting "graven images."16 Freedom of speech, press, assembly, and worship "are susceptible of restriction only to prevent grave and immediate danger to interests which the State may lawfully protect."17

The following year the Court decided Prince v. Massachusetts ${ }^{18}$ squarely on the issue of religious freedom, holding a woman subject to prosecution for allowing her nine year old niece to sell religious literature on a street corner in violation of child labor laws. The Court felt that the crippling evils of child labor were appropriate for legislative action, because society's interest in child welfare prevailed over the religious practices of children. The case is not helpful in determining guidelines because what the state niay do $m$ the interest of child welfare bears little necessary relationship to what it may do $\mathrm{m}$ the interest of adults. ${ }^{19}$ However, the Court did utilize a definite balancing test.

For the next sixteen years the Supreme Court refused to consider religious freedom questions..$^{20}$ The federal courts during this period continued generally to apply the secular regulation rule. State court decisions, however, varied greatly from the interest weighing approach of Barnette to the secular regulation philosoplyy of Reynolds. ${ }^{21}$

\section{Alternative Means Test}

It was not until 1961 in Braunfeld v. Browen ${ }^{22}$ that the Supreme Court again considered the question of religious freedom. It held there that Sunday closing laws applied to Orthodox Jewish businessnien who also closed on Saturday in accordance with their rehigious dictates without violating their free exercise of religion. The court placed great emplrasis on the "in-

15319 U.S. 624 (1943).

18 Forcing one to take a particular pledge is closer to the infringement of religious beliefs which were given absolute protection in Cantwell than infringement of religious acts. See notes 6-8, 12, 13 supra and accompanying text.

17319 v.S. at 639 .

18321 U.S. 158 (1944).

$10 \mathrm{Id}$. at 168 .

20 Richter v. United States, 340 U.S. 1892 (1950) (draft exemption); Corporation of Presiding Bishop v. Porterville, 338 U.S. 805 (1949) (zoning ordinances as applied to churches); Donner v. New York, 342 U.S. 884 (1951) (compulsory education); Labrentz v. Illinois ex rel. Wallace, 344 U.S. 824 (1952) (infant blood transfusions over parents' objection); Ohio ex rel. Dunham v. Board of Educ., 341 U.S. 915 (1951) (conpulsory vaccination of school children).

21 For a discussion of the positions taken by the different states see D. Manwaring, supra note 7 , at 245 .

22366 U.S. 599 (1961). 
directness" of the burden..$^{23}$ Braunfeld could both practice his religion and comply with the law; furthermore, though caused by adherence to a religious practice, the burden was economic. ${ }^{24}$ Chief Justice Warren writing for the Court said that where the state has a secular goal and only one reasonable method of achieving it, ${ }^{25}$ a law designed to accomplish this goal will be sustained even though it imposes an indirect burden on the free exercise of religion. The Court gave no indication of what test must be apphed if a direct burden were involved. Alternative laws suggested by the defendant were rejected by the Court because they would not accomplish the same goal. ${ }^{26} \mathrm{~A}$ rehigious exemption to the existing law was denied on two grounds: First, granting an exemption would undercut the goal of the statute-providing a day free of commercial activity; second, those granted a rehigious exemption might gain a significant economic advantage over other businesses closing in compliance with the laws. ${ }^{27}$

\section{Compelling Interest Test}

Two years later the Supreme Court again faced the issue of religious freedom in Sherbert $v$. Verner. ${ }^{28}$ In this case, its most recent articulation of free exercise, the Court held that a state cannot deny unemployment compensation to one whose unavailability for Saturday employment was rehigiously motivated. In so doing, the Court introduced a new consideration:

We must next consider whether some compelling state interest enforced in the eligibility provisions of the South Carohina statute justified the

23 Braunfeld was the first case to make this distinction: A direct burden was defined as an irreconcilable conflict between the individual's religious tenets and obedience to the law; one must yield. An indirect burden places a hardship on a religious practice but does not make the practice itself unlawful.

24 Braunfeld stated that he would be forced out of business if he remained closed two days a week. 366 U.S. at 601 . There are many instances in which an indirect burden will result in a much greater hardship on an individual than a direct burden. Being forced to forego a nonessential religious practice which would be classified as a direct burden is certainly Iess severe than losing a business.

25 Theoretically, there are always two possible alternative means: (1) developing a new statutory scheme that will accomplish the same ends without infringing on religious freedoun; or (2) providing an exemption within the same statutory scheme. Generally, only the second inethod will be considered by the court, unless an alternative statute is suggested by the person whose religious practice is infringed.

28 The suggestion of having all businesses close any individually selected day in seven would not accomplish the statute's purpose of having a uniform day of rest.

27 This economic factor considered separately does not seem to justify the holding. The great economic burden placed on the Jewish businessmen by not allowing the exemption outweiglis the minimal loss that all other busimesses might suffer by allowing the exemption. This coupled with the fact that first amendment rights would be infringed by not allowing the excmption makes Braunfeld a decision of questionable value as a precedent.

28374 U.S. 398 (1963). 
substantial infringement of appellant's First Amendment right. It is basic that no showing merely of a rational relationship to some colorable state interest would suffice; in this highly sensitive constitutional area, "[o]nly the gravest abuses, endangering paramount interests, give occasion for permissible limitation."29

The term "compelling state interest" is not self-defining. In Sherbert the Court concluded that there was no compelling state interest in denying a religious exemption. The goal of the statute-to provide welfare funds for those involuntarily unemployed-would survive the granting of such an exemption. ${ }^{30}$ The state had no compelling interest in avoiding speculative fears of fraudulent religious claims. ${ }^{31}$

The Supreme Court in Sherbert applied a two stage test, looking to see, first, burden on the religion and, second, whether there is a compelling state interest which justifies not permitting a religious exemption. This second step necessarily requires a consideration of the effect of the rehigious exemption on the purpose of the statute. ${ }^{32}$

In re Jenison ${ }^{33}$ illustrates the impact of Sherbert on the scope of free exercise. The Minnesota Supreme Court prior to the Sherbert decision, affirmed the criminal conviction of a woman who refused to serve on a jury because of religious objections. The United States Supreme Court reversed per curiam and remanded the case for further consideration in hight of Sherbert. ${ }^{34}$ Upon remand the state court reversed the conviction stating that there had been an inadequate showing that the state's interest in obtaining competent jurors overrode appellant's right to free exercise of her religion. $^{35}$

\section{E. Application of These Tests in People v. Woody}

People v. Woody ${ }^{36}$ represents the farthest extension of the Sherbert test to date. In a learned opinion embodying the compelling interest, alternative means, and balancing tests, the California Supreme Court held that niembers of the Native American Churcli who used peyote ${ }^{37}$ as the sacra-

$20 \mathrm{Id}$. at 406 (emphasis added). Note the similarity of this language with Barnette. See text accompanying notes 15-17 supra.

$30 \mathrm{Id}$. at 409.

31 Id. at 407 .

32 In Braunfeld, allowing some businesses to open on Sunday would work contrary to a uniform closing law. However, receiving unemployment compensation while refusing to work on Saturdays does not impair the purpose of welfare payments.

33267 Minn. 136, 125 N.W.2d 588 (1963).

34375 U.S. 14 (1963).

35267 Minn. at 137,125 N.W.2d at 589.

30 61 Cal. 2d 716, 394 P.2d 813, 40 Cal. Rptr. 69 (1964), noted in 17 Stan. L. Rev. 494 (1965).

37 Peyote is a spineless cactus which grows in Mexico and Texas. The properties of the 
mental heart of their religious worship were exempt from statutes prohibiting use or possession of peyote. ${ }^{38} \mathrm{~A}$ balancing approach was employed: the importance of the particular practice to the religion was weighed against the importance of the state interest and against the impact of a religious exemption on that interest. In this case, great weight was given to religious freedom since peyote represented the very essence of the Indians' religious experience. ${ }^{39}$ For the first time, a court determined the burden by examining whether a practice was "central" to the religion. ${ }^{40}$ The court also found that the state had no compelling interest in preventing the Indians from using peyote in their religion because that use presented only "slight danger" to the state and its law enforcement. ${ }^{41}$ Braunfeld required the state to show that there was no alternative means of accomplishing the same legislative ends without infringing on religious freedom. The court in Woody leld that the state had failed to meet this burden. ${ }^{42}$

\section{II}

\section{IEARY V. UNITED STATES}

These cases provide the backdrop for the Fifth Circuit's decision in Leary v. United States. All cases discussed in this Comment were cited and applied by the court with varying degrees of accuracy. ${ }^{48}$ The central

cactus are such that, when eaten, it produces extraordinary physiological and psychological effects. 17 EnCYCLOPAEDIA BRITANNICA 684 (1963).

38 Contra State v. Bullard, 267 N.C. 599 , 148 S.E.2d 565 (1966).

39 The peyote was considered the "theological heart" of their religion not only because it induced a particular ballucinogenic state but also berause it was an object of worship in itself.

40 Centrality is used here in an absolute sense: if the practice in question is not permitted it becomes impossible to practice the religion. It is not clear whether the centrality of peyote in Woody was a decisive factor in granting the exemption. On the same day the California Supreme Court remanded a companion case dealing with the conviction of a self-styled peyote preacher. The only question to be decided on remand was the sincerity of his beliefs. In re Grady, 61 Cal. 2d 887, 39 Cal. Rptr. 912, 394 P.2d 728 (1964). The court did not seem concerned with proof of the centraity of peyote in those beliefs.

41 The supreme court found no deleterious effects from using peyote. This contradicts the lower court's finding of dangerous effects. The supreme court rejected the state's claim that granting such an exemption would make narcotics laws unenforceable because of the difficulty of detecting fraudulent claims.

42 The court placed great emphasis on the fact that Arizona, Montana and New Mexico have all granted religious exemptions for peyote. $61 \mathrm{Cal}$. 2d at 723-24, $40 \mathrm{Cal}$. Rptr. at 75,394 P.2d at 819.

43 The court cites both Reynolds and Davis to support its conclusion, relying on the language which states that religious actions must be subordinate to criminal laws. See text accompanying notes 6-9 supra. The Reynolds court would not hesitate to decide this case against the defendant on the basis of its understanding of free exercise of religion. This Comment has tried to show the evolution of the concept of religious freedom in the decisions of the Court. If, however, the focus is on the narrow factual holdings of the cases, some support might be found for the proposition that crininal laws never yield to religious 
issue considered was, in the words of the court, "whether the conviction of appellant for violations of federal criminal statutes relating to marihuana -a psychedelic drug which the defendant claims he uses as a rehgious sacramental aid-contravenes the accused's First Amendment rights to the free exercise of his religion." ${ }^{44}$

\section{A. How the Court Determined a Compelling Interest}

The court concluded in Leary that a compelling interest justifies refusing a rehigious exemption. The particular method of analysis employed to reach this conclusion is unclear. There are three possible ways in which the court could have found a compelling interest in not allowing this exemption: First, consideration of all evidence submitted by both parties relative to the effects of marihuana use; second, acceptance of congressional belief as to the effects of marihuana and application of that belief to the granting of a rehioious exemption; and, third, consideration only of evidence and testimony of the 1937 Congressional hearings on the marihuana laws. ${ }^{45}$

The first method was not used. The court explicitly stated that evidence about the "so called harmless nature" of marihuana was "not pertinent"; nor was it "incumbent on the government to produce evidence to controvert testimony" on this question. No reference was made to the extensive documentation on the effects of marihuana in the briefs of both Leary and the government.

At the end of its opimion, after already having concluded that a compelling interest did exist, the court discussed the evidence and testimony submitted in the 1937 hearings. How relevant this evidence was to the court's conclusion is uncertain. The court considered this evidence either to determine whether there was a rational basis upon which Congress could have found a compelling interest or to determine whether there was in fact a compelling interest. The court's language strongly indicates that

actions. Barnette and Cantwell were both interrelated with issues of free speech; Prince and Braunfeld held against the religious practice; Sherbert did not involve a criminal violation. There have been no Supreme Court cases which have upheld religious actions which contravene criminal laws. But cf. In re Jenison, 375 U.S. 14 (1963). This criminal-noncriminal distinction suggests a contrary argument: if a constitutionally protected first amendment right to free exercise of rehigion is challenged by a criminal law with criminal sanctions (in this instance a felony with a long prison sentence), the government should have an even greater burden to justify such a challenge than where the consequence of a religious practice is a civil sanction only.

44383 F.2d at 853 .

45 A fourth method suggests itself: the personal knowledge and feelings of the court. "The danger is too great, especially to the youth of the nation, at a time when psychedelic experience, 'turn on,' is the 'in' thing to so inany, for this court to yield ...." 383 F.2d at 861 . 
it followed the latter approach. The words "rational basis" and "Congress could have found" do not appear in the opinion. Instead the court explicitly stated that it found the evidence "convincing that marihuana is a serious evil to society. Thus did Congress wisely and prudently enact this law and clearly meet the 'compelling state interest' test imposed in Sherbert v. Verner." ${ }^{\text {(66 }}$ This implies that the court made an independent judgment on the basis of the 1937 evidence and concluded that its findings correlated with those of the 1937 Congress. The test should not be whether there is a compelling interest as it could have been determined in 1937. The court, however, expressly refused to consider any other evidence. Such reasoning is particularly unsupportable in this area where the most significant scientific and clinical studies were made subsequent to the passage of the statute. ${ }^{47}$ The courts should make their judgment only after considering the most authoritative current evidence. ${ }^{48}$

The language used by the court implies that it relied most heavily on the second approach. Frequent reference is made to the "grave concern of Congress." The severe penalties imposed by Congress provide "insight" into congressional efforts to "control the use of this drug." The central issue, according to the court, was whether the regulated conduct "has posed some substantial threat to public safety, peace or order." To answer this question the court again referred to congressional belief: "Congress has demonstrated beyond doubt that it believes marihuana is an evil in American society and a serious threat to its people."150

46 Id. at 869 .

47 The most exhaustive clinical study was undertaken in New York City from 1939 to 1943. See The Mayor's Committee on Marthuana, The Marieruana Problems in the City of New YorK (1944). For other recent studies, see WHIT: House Conference on Narcotics aNd Drug Abuse Proceednggs (1963); Medical Society of the County of New York, N.Y. Medicine, May 5, 1966.

The court when looking to the 1937 hearings referred to testimony of the "injurious effect [marihuana] has upon the pubhic health and morals of this country," making special note of the testimony relating "criminal episodes of terrible character which accompanied its use." The court quoted the then Commissioner of Narcotics as saying, "This drug is entirely the monster Hyde, the harmful effect of which cannot be measured." 383 F.2d at 869 .

The findings of these more recent studies have consistently contradicted the testimony of the 1937 hearings. See also D. Solomon, TrE Marthuana Papers (1966).

48 There is no problem in this case of having the court consider current evidence since the legislative factfinding of thirty years ago is of questionable value in hight of the more recent studies. However, the problem might be resolved differently if the law were based on a recent legislative finding of fact. Whether the court must accept the legislative factfinding is a disputed question. A distinction must be made between accepting the legislative factfinding and then determining if there is a compelling interest on the basis of that finding or adopting a factfinding contrary to that of Congress and determining if there is a compelling interest on the basis of that finding. The former method is an undisputed right of the courts. However, heated controversy surrounds the latter method. See Karst, Legislative Facts in Constitutional Litigation, 1960 SUP. CT. REv. 75.

40383 F.2d at 859 .

50 Id. at 861 . 
But to meet the compelling interest test of Sherbert more is required than a consideration of congressional intent. The court should determine whether there is a compelling interest in the purpose of the statute as viewed by Congress. The legislative purpose of the marihuana statute in question, as interpreted by this court, is the preservation of "public safety, peace or order." It is admittedly not proper for the court to consider whether the use of marihuana by the general public is a threat to the public welfare. To do so would usurp a legislative function. ${ }^{51}$ The court should determine only whether the goal of preservation of public health, safety or order is a compelling interest. However, the court must not end its inquiry here. Sherbert clearly indicated that the state has the burden of showing it has no alternative means of accomplishing the same goals without infringing on religious freedom. ${ }^{52}$ The only alternative at issue in this case is a religious exemption to the existing statute. The court must determine whether a religious exemption would work contrary to the purpose of the statute; whether a religious exemption would endanger "public health, safety or order." To make a judgment on this question the court should consider evidence on the effects of marihuana. By grounding its judgment solely on congressional intent, without considering submitted evidence, the court strips itself of its judicial function of determining when an act of Congress has exceeded its constitutional limits. This is equivalent to saying that the will of the majority as reflected by Congress can override an individual's constitutionally guaranteed rights. Congress most hikely did not consider in 1937 whether a religious exemption was constitutionally required. At that time the Supreme Court still followed the secular regulation rule; religious acts were not afforded any constitutional protection. The Leary court, by considering evidence presented in this instance, could not have been accused of second guessing Congress. Although a court should not weigh legislative facts in determining general legislative purpose, it should weigh them in considering an individual's first amendment rights.

According to the court, appellant's rehance on Sherbert was "misplaced" and "inapposite on the facts." The court found a "paramount government interest in the enforcement of the laws relative to marihuana

51 If, however, constitutional rights of due process or equal protection are asserted to test the general constitutionality of marihuana laws, the court can then look to whether there is a rational relationship between the statute and the purpose for which it was enacted. United States v. Carolene Products Co., 304 U.S. 144, 153 (1938); Weaver v. Palmer Bros. Co., 270 U.S. 402, 410 (1926).

52 Sherbert v. Verner, 374 U.S. at 407 . This would seem to imply that the state has the burden to show that there are no alternative statutory means to curb the abuse without burdening the religion. A more practical interpretation would put the burden on the state to show why alternatives suggested by the one asserting religious rights will not be acceptable. 
is the protection of society. We cannot reasonably equate deliberate violation of federal marihuana laws with the refusal of an individual to work on her Sabbath Day and nevertheless claim compensation benefits." ${ }^{253}$

The court seems to distinguish between either criminal and noncrinninal or compelling and noncompelling interest. The former distinction alone is not sufficient. ${ }^{64}$ Presumably, the court found a greater governmental interest in the protection of society through enforcement of its criminal laws than in the preservation of public monies through denying welfare funds to undeserving claimants. While this is unquestionably true, it does not resolve the pivotal question as to what effect a religious exemption will have on the protection of society, and whether that effect will amount to a compelling interest which, would justify denying a religious exemption.

\section{B. Where the Court Found a Compelling Interest}

According to the court, the only danger in granting an exemption was the possibility of fraudulent religious claims making "the anti-marihuana laws meamingless ... and enforcement impossible." lent religious claims was explicitly rejected in Woody, ${ }^{60} \mathrm{Jenison}^{67}$ and Sherbert..$^{58}$ Three important judicial limitations militate against the likelihood of such fraudulent claims: First, the courts, not the jury, will determine whether these are religious behefs; ${ }^{619}$ second, the jury then must determine whether these beliefs are leeld in good faith; ${ }^{00}$ third, failure to establish religious behefs held in good faith will result in a felony conviction.

Before any acts can be given first amendment protection under the free exercise clause, the court must make a judicial determination of whether these acts are religious in nature. Mere assertion of their religious nature by the defendant will not bar judicial review. ${ }^{01}$ Generally, how-

63 Leary v. United States, 383 F.2d 851, 860 (1967).

54 For a discussion on this point, see note 43 supra.

65383 F.2d at 861.

5861 Cal. 2d at 723, 394 P.2d at 819, 40 Cal. Rptr، at 75.

57267 Minn. at 137,125 N.W.2d at 590.

68374 U.S. at 407.

59 See United States v. Seeger, 380 U.S. 163 (1965). The Suprenre Court concluded that the beliefs in question were religious as the term was used in the Selective Service Act. It is reasonable to assune that the courts will adopt the same form of inquiry wisen referring to religion as used in the first amendment.

60 The trier of fact is not to consider the truth or falsity of the particular belicf, but only whether it is held honestly and in good faith. United States v. Ballard, 322 U.S. 78,88 (1944).

61 See note 64 infra. 
ever, courts will avoid inquiry into whether the defendant's beliefs are religious if they find that the first amendment will not protect the particular practice even if it were of a religious nature. ${ }^{62}$ The jury must ferret out those who seek "to wear the mantle of religious immunity merely as a cloak for illegal activity."63

Every person who makes a claim for exemption must be willing to suffer a felony conviction if he fails to hurdle these first two judicial barriers. It is unlikely that people will be encouraged to violate federal marihuana laws in hopes of successfully asserting a religious defense. If the defense is uplield in the first instance, those charged in the future with marihuana violations would naturally be more inclined to use religion as a defense. ${ }^{64}$ But eacl person who makes such a claini must prove to the satisfaction of the judge and jury first that his beliefs are religious and, second, that they are held in good faith. To deny a religious exemption out of fear of fraud indicates a lack of confidence in our judicial process. However, if there are any weaknesses within our judicial system they will be more inclined to work against rather than for the religious claimants. Although the jury would be carefully instructed to consider not the truth of a belief, but ouly the sincerity with which it is held, it will find this distinction difficult to maintain and impossible to control. The good faith test is therefore likely to work in favor of conventional, institutional beliefs, and against esoteric, individual beliefs.

\section{III}

\section{EVAIUATING "FREE EXERCISE" CLATMS}

\section{A. Weighing Religious Burdens}

Weighing burdens on rehigions is a sensitive task; no meaningful solution has been suggested by either the courts or legal scholarship. The two methods used have done little to resolve the problem. The Braunfeld classification of direct-indirect religious burdens ${ }^{65}$ can lead to harsh results, of which the Braunfeld case itself is a good example. The defendant

62 The Leary case, itself, is a good example. The court assumed that Leary used maribuana in a religious context for the purpose of determining whether that practice is protected by the first amendment.

63 People v. Woody, 61 Cal. 2d 716, 726, 394 P.2d 813, 821, 40 Cal. Rptr. 69, 77 (1964).

$64 \mathrm{~A}$ California court of appeal has rejected a religious defense to a marihuana prosecution stating that the defendant offered no evidence that his use of marihuana was rehigious in any sense of that term. People v. Mitchell, 244 Cal. App. 2d 176, 52 Cal. Rptr. 884 (1966).

65 Donaldson, Freedom of Religion and the Recent Sunday Closing Laws Case, 3 WM. \& MARY I. REv. 384 (1962), notes that when a state statute is burdening interstate commerce the courts only look to whether there is a burden, without classifying as direct or indirect. There is no reason why the protection afforded interstate commerce should be greater than the protection afforded freedom of rehgion under the first amendment. Id. at 394. 
was forced to choose between losing his business or giving up an important tenet of his religion. ${ }^{68}$ Sherbert downplayed the importance of this distinction; the Court's only inquiry was as to whether a burden was placed on the religious practice. ${ }^{67}$ No attempt was made in either Braunfeld or Sherbert to weigl the burden in terms of economic loss. ${ }^{88}$

The central-peripheral distinction of Woody is not as helpful as it may appear at first. There liave been few instances in which the religious infringement could be classified as central according to the Woody definition. ${ }^{60}$ Indeed, no other case discussed above involved such a total infringement. This method of classification offers no assistance in the great majority of cases that will be classified as peripheral. The problem of determiming centrality itself may be fraught with difficulties that do not appear in Woody. The claim in that instance was uncontested by the state. The shortcomings of this test become apparent when the religious acts concerned are not as obviously central as the use of peyote by the members of Native American Cluurch in Woody. Where an act is ritualistic and the government contests its centrality to the particular religion the courts must act as the final arbiter in questions of religious doctrinequestions more appropriately decided by prelates than by judges. However, centrality does serve one useful function. In those few instances where it can be clearly established, it represents the most significant burden on rehion possible; the state must slow a very great interest to justify such a total infringement. Beyond this, however, the centralperipleral distinction is of limited utility.

The burden on Dr. Leary's religion, while not asserted to be central, nevertheless appears to be quite substantial. Leary testified in the trial court that mariliuana plays an integral part in his religious practice; that it is a sacramental aid which substantially facilitates his religious beliefs; and that it enables him to attain certain levels of consciousness that are important to the practice of his religion. ${ }^{\mathbf{7 0}}$

Courts will, of course, continue to weigh religious burdens. The lack of an adequate systematic method suggests that there will be no uniformity. It has been held that courts must give great weight to the

68 See note 24 supra.

67 The Supreme Court remanded Jenison (a direct burden) to be decided in liglit of Sherbert (an indirect burden), implying that it places no importance on the direct-indirect distinction. See notes 33-35 supra and accompanying text.

68 Sherbert referred to Braunfeld as being a less direct burden. 374 U.S. at 408. This comparison is difficult to maintain in light of the fact that Braunfeld's burden was loss of his business while Sherbert would have foregone only 26 weeks of unemployment benefits.

69 For the Woody definition, see note 40 supra.

70 Brief for Appellant at 59. 
defendant's testimony concerning his religious beliefs. ${ }^{71}$ However, in the absence of guidelines courts may incorporate their particular predilections into the weighing process. ${ }^{72}$

\section{B. Determining the Compelling State Interest}

The words "compelling state interest" in normal usage suggest an area of serious governmental concern that would, if threatened, have grave implications for society. The Supreme Court, however, lias not used the term in this literal sense. In Sherbert the court confirmed that Braunfeld, Prince and Reynolds all involved compelling interests because they posed a "threat to public safety, peace or order." In In Braunfeld a religious exemption would have subjected the general public to a minimal increase in commercial activity on its legally desiguated day of rest. ${ }^{74}$ The nine year old niece in Prince would herself have been liarmed from exposure to the corrupting elements of the street. While the distressing evils of polygamy asserted by a nineteenth century court cannot be as seriously contended today, the Court lias indicated that it still believes the resulting harms would justify free exercise limitations. ${ }^{75}$ This legal application of the term "compelling interest" has been misleading. The word itself conveys an impression of gravity which lias not been present in these cases. In view of the Court's decisions, the word "substantial"meaning something nore than comfort and convenience-is more appropriate.

The dearth of cases involving free exercise lias made it difficult to predict what elements must be present to establish this "compelling" interest. It is useful to separate those wliose interests may be at stake into four distinct categories: ${ }^{76}$ First, the religious actor; second, voluntary associates of the religious actor; third, the nonconsenting public in

71 United States v. Seeger, 380 U.S. 163, 184 (1965). (Conscientious objection case construing "religion" as used in the Selective Service Act.)

72 For example, see the statement of the Leary court quoted in note 45 supra.

73374 U.S. at 403.

74 It is interesting to note that Justice Brennan, dissenting in Braunfeld, did not feel that a uniform day of rest was a strong enough state interest to justify the burden placed on Braunfeld, 366 U.S. at 614. However, when writing for the court in Sherbert, Justice Brennan referred to a uniform day of rest as a strong state interest. 374 U.S. at 408. Three justices in Sherbert writing separate opinions felt that Sherbert necessarily overruled Braunfeld. 374 U.S. at 417 and 421 . This compromise by Justice Brennan indicates that he too may be counted with this group.

75 Cleveland v. United States, 329 U.S. 14, 19 (1946).

76 For an excellent article that considers these categories see Galanter, Religious Freedom in the Untited States: A Turning Point, 1966 WIs. L. REv. 217. See also Giannella, Religious Liberty, Nonestablishment, and Doctrinal Development: Part I. The Religious Liberty Guarantee, 80 HARv. L. REv. 1381 (1967). 
general; and, fourth, nonconsenting individuals. A careful evaluation by the court of the testimony submitted is necessary to determine whose interest would be affected by a rehioious exemption. A finding in the first category that marihuana will cause physical or mental harm to Leary alone might not be sufficient. Society's interest in keeping its citizens healthy may have to give way to an individual's religious freedom. In re Brook's Estate ${ }^{77}$ held that a woman with only adult children could refuse blood transfusions on religious grounds despite the danger of death. A finding in the fourth category that marihuana causes aggressive crime threateming individual rights would unquestionably justify demal of a religious exemption. The middle categories are less clear in their outcome. There will of course be shadings and degrees within each category. The lines of separation between these categories are themselves sliaded. This method of analysis is not designed to provide a mechanical formula to predict the outcome of each case; the approach is one of form, not substance. The decision must ultimately remain subjective; but the subjectivity would be narrowed to a definable area. There is no current precedent that will adequately guide the court to a proper decision. The critical point at which an interest becomes compelling must be left to the facts in each case and to the good sense of the presiding judges.

It is beyond the scope of this Comment to evaluate the evidence relative to the effects of marihuana. But to do so is not beyond the scope of the judiciary where first amendment riglts are threatened. The court should consider all of the available evidence, determine whose interests will be adversely affected, and make a judgment as to whether those interests are sufficient to justify the particular burden placed on the individual's rehgion.

\section{CONCLUSION}

Freedom of religion has not been a burning issue within our constitutional framework. Religious practices historically have been institutional, being governed by religious doctrines which have reflected the mores of the religion's composite membership. Doctrine follows rather than leads social innovation. And, although it may be behind the general social scheme, doctrine is rarely in conflict with the legal order.

This concèpt of religion is undergoing change. A more individuatized conception of rehgion is emerging. The Supreme Court acknowledged this in United States $v$. Seeger ${ }^{78}$ when it admittedly relied heavily on the writings of theologian Paul Tillich:

$7 \tau 32$ Tll. 2d 361, 205 N.E.2d 435 (1965).

78380 U.S. 163 (1965). 
[I]f that word [God] has not much meaning for you, translate it, and speak of the depths of your life, of the source of your being, of your ultimate concern of what you take seriously without any reservation ... [The "Law of Religion" is] the great attempt of man to overcome his anxiety and restlessness and despair, to close the gap within himself, and to reach Immortality, spiritualism and perfection ... [ "Rehigion" stands for] the feeling for the inexhaustible mystery of life, the grip of an ultimate meaming of existence, and the invincible power of an unconditional devotion. ${ }^{9}$

Religion is experiencing an upsurge of personalism. What men do to overcome their "anxiety and restlessness and despair" will be called on some occasions religious actions. Each individual may begin to choose for himself, unfettered by religious doctrine, how to "close the gap within himself, and to reach immortality, spiritualism and perfection." In choosing his method an individual is more likely to stray from conventional social structure than is a group worshiping together in accordance with religious doctrine. Leary involved an individual who had diverged from the general legal order by using drugs to reacl new levels of consciousness in seeking the ultimate truths of existence.

Society may gain from these religious practices by permitting individual fulfillment and providing a means for retesting its existing values. But society will also suffer either collectively or individually, when its interests are threatened by these practices. Freedom of rehgion may well become a burning issue in the future. The courts will have to determine how mucl society is willing to tolerate before it draws the hine of "compelling interest."

John R. Phillips

79 P. Trmich, The Shatring of the Foundations 57 (1948). 